\title{
Elena Ioriatti*
}

\section{Comparative Law and EU Legal Language: Towards a European Restatement?}

https://doi.org/10.1515/gj-2020-0070

Published online February 17, 2021

Abstract: Despite the ongoing developments in comparative law studies, European legal language is still in want of responses with regard to its own characteristics and impact in the Member States. This article suggests an interdisciplinary perspective, that of comparative law and semiotics, as well as the observation of the normative forces grounding the practices of EU law in the Member States. As a dialogical conclusion, a Restatement will be suggested, where EU concepts could be channeled. This intellectual tool could be relevant in legal education too and favor the institutional dialogue among national and European actors of the multilingual legal process.

Keywords: EU legal concepts, comparative law, empirical research, national grounding forces, semiotics meta-concept.

What's in a name? That which we call a rose by any other name would smell as sweet William Shakespeare

\section{Introduction}

The central place occupied by language in comparative law studies has long been recognized by the scientific community and the study of legal translation, in its manifold forms, is nowadays a well-established field of research. However, the only apparently stable relationship between comparative law and language where comparative law methodology is applied to legal translation as the object of analysis - is of an unrestrainable dynamic nature, as accompanying the current changes of the world of law. This is particularly visible in the EU multilingual contexts, where comparative law ensures proper reading of the legal language complex interconnection among Eu legislator and national courts. As we will see in this contribution, when EU law is observed and qualified through comparative law

*Corresponding author: Elena Ioriatti, Faculty of Law, Trento University, Trento, Italy, E-mail: elena.ioriatti@unitn.it 
methodology - in combination with other methods like that of semiotics -, it becomes clear that a consolidated EU legal language is under creation, as the result of a synergy among EU legislative concepts and the outcomes of national court interpretations. Here comparative law goes so far as to become a catalyst of an already existing phenomenon, of a European Union legal language consolidation, which would not be visible and run the risk of dissipating its own potentialities without a proper methodological support.

This article will first analyze the evolution of the role of language in comparative law studies, starting from the beginning of the last century. Language, and in particular legal translation, was initially perceived by comparatists as an instrument of comparative law studies, and not as an object of research. This underestimation was originated by the idea of legal concepts being transferable in all languages with the same meaning, as characterized by trans-border validity. The theme of universal validity of concepts was a "side-effect" of another idea, namely that of norms having an objective meaning, exhaustively defined by the words of the legislator. By the end of the 50s, legal philosophers and linguists together with jurists, contributed to clarify that the meaning of norms is not defined by the legal text only, as norms exist beyond the words of legislators; the meaning attributed by interpreters does contribute too. Thus, the awareness of the need of a constant adaption of legal concepts transferred across languages stimulated an upsurge of interest in comparative law studies.

This modern evolution of law and language studies was also favoured by the Europeanization and globalization of law, a field of research in which comparatists started to occupy a central place. Particularly, a great deal of intellectual efforts have been devoted to the exploration of multilingual law and with the passing of time a discipline that might eventually become known as "EU law and language studies" is beginning to emerge.

The second part of the article focuses especially on the main recent studies in the field of legal language of the EU. The expression "main recent studies" is mainly intended to refer to monographic research published in the twenty-first century, even though some relevant edited books and individual essays in law journals will also be mentioned. As it will be underlined, the time covered represents the beginning of a period of major interest in EU multilingual law, particularly in comparative law, due to the growing importance of the role of language in legal studies, as well as to multilingual legislation and formulation of uniform principles in Europe and worldwide.

After having briefly described the state of art, the author posits that in order to proceed in the study on EU legal language, two developments of the research could be relevant: methodological interdisciplinarity - semiotics in particular - and attention to the norms elaborated by national interpreters - judges, practitioners, 
legislators - in applying or enforcing EU law to the Member States. The findings of a case study on the 2018 version of the EU Framework Directive 2008/98 on waste will show how national courts, principally, but legislators too, do contribute to the meaning of EU concepts and to the consolidation of a uniform EU legal language.

Together with a general overview of the results of the case studies, the final part of the article will also suggest that in order to raise awareness on the specificity of EU legal language an intellectual instrument - a European Restatement - could be drafted in the form of an experimental model. This instrument could also favor the establishment of specific programs of EU multilingual legal education offered in all the official languages of the Member States.

\section{Comparative Law and Language}

One of the interesting aspects of being a comparatist in the twenty-first century in Europe is a sense of tension. We all sometimes experience that feeling due to the temptation of finding a new order in the world of law, to qualify everything again, in a juridical environment that is "on the move." This is partly due to the relationship among the components of the legal world - the law, the language, the material fact - which does not always look the same, as it did in the past.

At the end of the nineteenth century, a young comparative law science ${ }^{2}$ was immerged in the social context of State unifications; the national codifications and the different solutions enacted draw the attention of comparatists to the need to analyze and understand all those new legislative models. Implicitly or explicitly, the underlying aim of comparative law was that of uncovering the commonalities of the different legislations. The strong belief that common solutions could be

1 François Ost, "Law as Translation", in The method and the culture of comparative law. Essay in Honour of Mark Van Hoecke, eds. M. Adams and D. Heirbaut (Oxford and Portland, Oregon: Hart Publishing, 2014), 76.

2 On the history of comparative law see Olivier Moréteau, Aniceto Masferrer, and Kjell A. Modéer, “Comparative Legal History”, (Elgar online), https://www.elgaronline.com/view/edcoll/ 9781781955215/9781781955215.xml (2019). On a worldwide overview of comparative law: Mathias Reimann and Reinhard Zimmermann, The Oxford Handbook of Comparative Law (Oxford: Oxford University Press, 2019). On the future of comparative law see Rodolfo Sacco 2018. "Le passé, le présent et le future du droit comparé”, in The Past, Present and Future of Comparative Law/Le Passé, le Présent et le Future du Droit Comparé, Ceremony of 15 May 2017 in Honour of 5 Great Comparatistes/Cérémonie du 15 mai 2017 en l'honneur de 5 grands comparatistes, eds. K. BoeleWoelki \& D.P. Fernàndez Arroyo, (Cham (Switzerland): Springer 2018), 103 and 111. For an overview of some core contributions on comparative law over time see: Mauro Bussani, Ugo Mattei (eds: The Cambridge Companion to Comparative Law, Cambridge: Cambridge University Press, 2012). 
found in foreign national codes, but simply expressed differently, came from the idea that post-revolutionary norms were founded on logic and reason, and so had to be necessarily uniform. ${ }^{3}$ This research of common solutions was gently accompanying the social need for unity of civilizations and carried out with method and evaluation criteria pertaining to all sciences. It is in this phase of its history that comparative law itself was confirmed as a science, thus concluding the well-known debate that reduced it to being a simple method of legal research.

It is easy to imagine that in this atmosphere the first Congress of Comparative Law, held in Paris in 1900, ${ }^{4}$ recalls today the romantic image of the Congress Solvay of $1911,{ }^{5}$ the first meeting of worldwide leading scientists, which was the crib of the discussion of some of the new theories in physics.

Even if comparative law scholars might have been initially perceived as "exotic" jurists, concentrated on handling an undisciplined discipline, at that time pluralism had no room in their research agenda: their destiny was that of researchers moving to the future, but still carrying on their shoulders the heritage of the Pandectist School of law. The Founding Fathers of comparative law took their first steps in a world in which the relationship among the law, the language and the material fact ensured from a clear order and - reminiscent of the Puchta pyramids too -, at least on the Continent, still had its core aim in the juridical syllogism.

Language, in particular, was in a stable, but ancillary position in the normative discourse, as legislation was often monolingual and norms formulated through concepts expressed with words rooted in the linguistic and cultural tradition of the judge called to apply them.

At that time, even in bilingual legislation, concepts were meant to have transborder universal validity, and to exist in any language with the same meaning. ${ }^{6}$ Such shared idea was conveyed by the role that the neologisms of the Pandectist School had in making German law imitated as a model in other legal systems. That huge circulation of models was possible also because it was founded on the belief that in any language there was a word in which German concepts - "Rechtsgeschäft”, for instance - could be accommodated, without losing their original meaning. ${ }^{7}$ Furthermore, this undiscussed belief was accompanied by

3 Rodolfo Sacco, "Legal Formants: A dynamic Approach to comparative Law", The American Journal of Comparative Law, XXXIX (1991): 1-34 and 343-402.

4 The Congress of the Société de Législation Comparée.

5 The first of the Solvay Congresses was held in Brussels in 1911 and was attended by, among other world leading physics, Marie Curie, Albert Einstein, and Max Planck.

6 Rodolfo Sacco, "Dall'interpretazione alla traduzione", in Interpretazione e traduzione del diritto, ed. E. Ioriatti (Padua: Cedam, 2008), 3-12.

7 An example is the Italian neologism "Negozio giuridico" transposing the German "Rechtgeschäft.” See Sacco 2000, p. 236. 
hermeneutical studies, according to which norms - and so words, and so legal concepts - had an objective meaning, exhaustively defined by the words of the legislator.

Needless to specify that, in this environment, translators were invisible actors of the legislative process as well as among academic circles too. Legal translation was simply innominate, perceived as an implicit activity of comparative law methodology and having no dignity of existence as a discipline. As noted earlier, the research approach followed at that time by comparatists was that of uncovering the expected commonalities underneath different rules. Notably, comparative law research mostly meant venturing into foreign environments, in which the comparatist's playing field was a place delimitated by four "cardinal points:" the law, the language, the material fact, and a clear role of the actors of the legal process.

The research posture of the comparatist was, therefore, that of investigating the relationship between law and language from inside.

In the twentieth century, some important well-known events started to change comparatists' panorama. In the 1940s Rodolfo Sacco had already discovered and motivated the non-existence of an objective meaning of the norm and of its normative declaration. ${ }^{8}$ German legal hermeneutics ${ }^{9}$ focused attention on the role of the interpreter. It also contributed to uncover the fact that the legal text has no objective meaning, simply expressed by the word of the legislator, as the judge does contribute to elaborate this meaning too. Thus, norms exist beyond legislative texts, and not being objective, meaning is not guaranteed by the universal value of the concepts expressed by the words, which compose the text.

Precisely because of the signals and importance of these scientific theories, the illusion that any legal concept could pass untouched through languages, maintaining the same original meaning, soon caved in. This evolution built up scholars' awareness in legal translation too, by underlining the fact that while analyzing terms of different legal systems, not only the language, but also the concepts themselves and their legal effects, had to be constantly revised, in order to grant the original meaning. Despite the awareness of the need for constant conceptual adaptation in legal translation, this activity was not automatically upgraded to a recognized scientific discipline. However, at least in these assertive investigations of commonalities among legal systems, legal translation was no longer a simple means of expressing foreign law, but started to be perceived as a method.

8 Rodolfo Sacco, Il concetto di interpretazione del diritto (Turin: Libreria Scientifica Giappichelli, 1947), 31.

9 Hans-Georg Gadamer, Wahrheit und Methode: Grundzüge einer philosophischen Hermeneutik. (Tubingen (Germany): Mohr, 1960); Josef Esser, Vorverständnis und Methodenwahl in der Rechtsfindung (Frankfurt (Germany): Athenäum Fischer Verlag, 1972). 
In this atmosphere, it is no coincidence that studies on legal language and translation initially grew outside the realm of the law, finding a place in linguistic and philosophical disciplines. Back in the nineteenth century, Charles Sanders Pierce, the founder of semiotics, had already developed theories about the sign, comprising three elements: the object, the representamen, and the interpretant. ${ }^{10}$ In his posthumous opera Cours de linguistique générale, (eds. Bally and Sechehaye), ${ }^{11}$ Ferdinand de Saussure explained to linguists that the word is a signifier, that the concept which corresponds to this word is a signified, and the reality which corresponds to the signified is the referent. But it was later on that Austin (1962) and Searle (1969), ${ }^{12}$ together with other linguists and philosophers, clarified that legal language has no referents, as the reality of the law is composed by words (statutes) or opiniones (customs), having no correspondence in the real world. As a consequence, a signifier never has a signified able to go beyond its own linguistic area and words in different languages do not perfectly coincide. ${ }^{13}$

Approximately in that same period, in comparative law studies, Rodolfo Sacco's theory of legal formants ${ }^{14}$ rippled the surface of the legal systems, which proved not to be flat, but a three-dimensional legal environment in which legislation, case law, and scholarly writing might diverge and not always be in harmony in solving a legal problem. Even though seamlessly, the formants in legal studies and the

10 Charles Sanders Peirce, “What is a Sign?”, CP. 2.285 (1895).

11 Ferdinand De Saussure, Cours de linguistique Générale (Paris: Payot \& Cie, 1916).

12 John Langshaw Austin, How to do Things with Words (Oxford: Oxford University Press, 1962); John Searle, Speech Acts. An Essay in the Philosophy of Language (Cambridge: Cambridge University Press, 1969).

13 Rodolfo Sacco, “Langue et Droit”, in Langue et Droit, XV International Congress of Comparative Law (Bristol 1998), Collection des rapports, ed. E. Jayme (Brussels: Bruylant, 2000), 238.

14 Rodolfo Sacco, "Définitions savantes et droit appliqué dans les systèmes romanistes", Revue Internationale de Droit Comparé (1965): 827-837. Unlike the traditional and positivist approach, which simply identifies law as the product of the official sources of a given national legal system, the theory of the legal formants, a methodology involved in comparative law science, presumes the existence of a plurality of other legal norms and institutions, which are active components - "formants" - and contribute to the actual feature of a legal system too. In essence, formants are norms, but which do not necessary coincide with those norms produced and contained in the official sources of the law of the legal system under analysis. This always happens when statutes are analyzed, as in all the legal systems legislation is an important, official source of the law. Thus, the so called "legislative formant" coincides with the legislation, as a source of the law. However, there are many other different types of legal formants. The "case law formant", as referred to the norms contained in the court decision is an official source of the law in the common law countries, but not in the civil law ones. The same happens with the interpretation given by scholars ("scholarly formant"), which suggested or interpreted rules have the status of official legal rules in some legal systems (e. g. the Muslims legal systems) and are differently considered in many other ones. The thesis suggested in this Chapter is that national case law and Member state legislations implement EU directives as "legal formants" and so component of those national legal systems. Sacco 1991. 
linguistic structuralism echoed each other. Debates within and about the nature of legal languages flourished in semiotics, while the analysis of the formants among legal systems implies the comparison of different legal languages among and inside the same legal system (the legal language of legislators, judges, scholars).

Moreover, in Denmark, Ole Lando imagined the European Principles of Contract Law (PECL), ${ }^{15}$ while the attention of the scientific community on a possible European Civil Code ${ }^{16}$ was attracted worldwide and Christian von Bar coordinated the Study Group on a European Civil Code and later contributed to the Draft Common Frame of Reference. ${ }^{17}$ In Italy Ugo Mattei and Mauro Bussani launched the project The Common Core of European Private Law. ${ }^{18}$ In shaping new principles, jurists became aware that the construction or uncovering of uniform principles and norms for Europe implies the creation of a common, working language and that the legal language is not just able to transmit a legal meaning, but also build a new common - as such or as shared - concept to various legal traditions.

Above all, the European Union, and particularly the Court of Justice of the EU (hereinafter CJEU), ${ }^{19}$ spread the message that European multilingualism grants the uniqueness of a legal norm, even if this norm is expressed in all the official national languages.

Essentially, starting from the eighties of the last century, observing the law, the language, and also the role of actors involved in the legal process (the national legislator and judge, the EU translator and lawyer-linguist, the CJEU, the EU legislator) started to mean to look into a sort of kaleidoscope.

The comparatists, therefore, started to observe the relation between law and language from the outside, as a new playing field of research, ${ }^{20}$ in which they, as scientists, were pushed at the forefront.

15 Ole Lando, "Principles of European Contract Law: An Alternative or a Precursor of European Legislation”, Rabels Zeitschrift für ausländisches und internationales Privatrecht/The Rabel Journal of Comparative and International Private Law (1992), p. 261-273.

16 Arthur S. Hartkamp et al., Towards a European civil code, fourth rev. and exp. ed (Alphen aan den Rijn: Kluwer Law International, 2011).

17 Christian Von Bar et al., Principles, definitions and model rules of European private law: Draft Common Frame of Reference (DCFR) (Munich: Sellier, European Law Publishers, 2009).

18 Mauro Bussani, Ugo Mattei, "The Common Core Approach to the European Private Law", Columbia Journal of European Law (1997/1998), p. 339-356

19 See for all: Case 283/81 - Srl CILFIT and Lanificio di Gavardo (SpA) v Ministry of Health.

20 This attitude, paradoxically, seems the other side of the moon, of what has been defined "comparative law ceasing to study the relationships between juridical systems viewed from outside and it is becoming the study of integrated law.”(Ost 2014, p. 77). In reality, in the opinion of the author of this article, the recent attitude of comparative law to analyse the connection between law and language is a prerequisite of the study of both integrated law and the relationship among different legal systems. 
For these and other reasons, the comparison made at the beginning of the twenty-first century is intertwined with attempts made before, but seamlessly. However, all these developments have certainly favored the growth of a specialist literature in the field of EU law and language and, with the passing of time, the consequences of framing the law in a plurality of languages have been added to the research agenda of comparative law scholars more and more.

\section{Law and Language Literature}

As noted in the previous paragraph, in the atmosphere of enthusiasm of the eighties for the relation between law and language, the way in which problems of bilingualism or multilingualism translation were handled by the variety of experiences of normative pluralism around the world was gradually perceived as a promising field of research. An example is the special issue of the review "Meta" on legal translation, published in 1979, under the direction of Jean-Claude Gémar. ${ }^{21}$ Later on, in 1986, the problems of legal translation were the subject discussed in Sydney by the International Academy of Comparative Law $^{22}$ and in 1998, "Langue et droit," was selected for a general report at the XVth International Congress of Comparative Law, held in Bristol. ${ }^{23}$

It is not surprising that at that time European comparative law scholars firstly turned to Canada to carry out their studies. ${ }^{24}$ The observation of Canadian literature allowed researchers to understand how the crucial aspect of multilingual legislation is the national interpretation and application of the multilingual normative declaration. ${ }^{25}$ The fruitful interaction between Canadian and European research soon highlighted structural differences between

21 Jean-Claude Gémar (dir.), "La Traduction Juridique” (special issue), Meta. Journal des traducteurs, Vol. 24, 1. (1979).

22 A special issue of the Review Les Cahiers de droit (Volume 28: 4, 1987) was dedicated to "La traduction juridique," and published the national reports written by Sacco, Beaupré, de Groot, Herbots, and Kitamura.

23 The proceedings of that session were published in Eric Jayme, (ed.)., Langue et Droit, XV International Congress of Comparative Law (Bristol 1998), Collection des rapports, Bruxelles: Bruylant (2000).

24 See for all Michael Beaupré, Interpreting bilingual legislation (Toronto: 2. Aufl., 1986); JeanClaude Gémar., and Nicholas Kasirer, Jurilinguistics: between law and language. Jurilinguistique: entre langues et droit (Bruxelles; Bruylant. Montréal: Thémis, 2005).

25 Luca Castellani and Rodolfo Sacco, Les multiples langues du droit européen uniforme (Turin: L'Harmattan, 1999); Rodolfo Sacco, L'interprétation des textes juridiques rédigés dans plus d'une langue (Turin: L'Harmattan, 2003). 
the consolidated Canadian multilingual experience and the European Union, as the main original world effort for the creation of uniform means of law expression of a unique system of law. One particular aspect sounds almost obvious: unlike Canada, the EU is not a State, but an international organization having specific tasks, principally the completion of the Single Market. Consequently, in EU norm the legislative intent is not to be found principally in a message addressed to a social group, but in the harmonizing aim of each single European directive or regulation. Furthermore, in Canada, translators of the two official versions - French and English - can frequently rely on concepts consolidated in a pre-existing legal tradition. This happens particularly in the translation of provincial law, but even Federal legislation often deals with fields of law that are not unfamiliar to the jurists belonging to the western legal tradition, ${ }^{26}$ albeit in the diversity of legal and linguistic cultures of the civil law and the common law systems.

Differently, the European Union is not founded on a pre-existing legal culture or tradition and consequently the language reflects the artificial construction of an entirely new legal system as it is. ${ }^{27}$ EU translators and lawyer-linguists are neutralcultural drafters of an entirely newly formulated law, having the mandate to make terminological choices and also to create neologisms. Even though EU translators are expected to simply translate, and lawyer-linguists to maintain legal equivalence among the different language versions, de facto since the very beginning of the EU adventure, they have been creating a new EU legislative legal language, not rooted in any national legal culture.

The origin of this language of EU law is the tensity between the obligation of enacting the EU harmonized legislation in all the official languages ${ }^{28}$ - normative multilingualism - and the effective achievement of this task from a substantive point of view, in terms of transferring the same meaning and legal effects in every Member state.

Indeed, as to multilingualism, it is well known that ever since the Treaty of Rome was signed, establishing the European Economic Community, this regime was chosen as the European Union's official linguistic system, and this has remained basically unchanged until today as then definitely confirmed by the Lisbon

26 See the bilingual official website of the Government of Canada: https://laws-lois.justice.gc.ca/ eng/acts/

27 Antonio Gambaro, "Jura et Leges nel processo di edificazione di un diritto privato europeo", Europa e Diritto Privato (1998): 993-1018; Antonio Gambaro, “A proposito del plurilinguismo legislativo”, Rivista Trimestrale di Diritto e Procedura Civile (2004): 287-300.

28 For an analysis of the aim of the multilingual regime of the European Union particularly focusing on legal drafting see Stefaan Van Der Jeught, EU Language and Law, (Groningen (NL): Europa Law Publishing, 2015), p. $103 \mathrm{ff}$. 
Treaty: art. 342 of the Treaty on the Functioning of the European Union recalls the content of the precedent primary law, unanimously assigning to the Council, the decision regarding the EU's linguistic regime. This language regime was soon enforced by the EEC with the first Regulation, n. 1 dated 15 April $1958,{ }^{29}$ regarding the Community linguistic system. In the original version, and after having established the four original official languages of the European Economic Community (Italian, French, Dutch and German), the regulation provided, among others, the obligation to enact documents and other texts of general interest in all the official languages. ${ }^{30}$ This is the principle of linguistic equality, that includes the equal authenticity of all linguistic versions and, from an operational point of view, involves the obligation to translate secondary law in all of the official languages of the Union.

Nevertheless, finding a functional equivalent for every single legal concept and norm of this new EU legislation in each of the official national legal languages would be technically impossible. As everybody knows, transferring the legal meaning of a concept from one legal system to another often ends up in a compromise. Translating one concept into 24 national legal languages simply multiplies this complexity.

So, the tension between the institutional obligation of enacting the harmonized legislation in all official languages and the technical difficulties of translation have been managed through an autonomous "dictionary" in which European law is constantly created through neologisms. Each term is shaped so that all languages formally have the same EU definition in common $^{31}$; this "translation" strategy leads a single concept to acquire twenty-four labels, each one having the same meaning, like forms of inter-lingual synonyms. ${ }^{32}$ The underlying idea - grounded on semiotics methodology too, as will be explained below - is that each of the authentic texts contributes to the meaning of the EU autonomous norm and turns the signified as the ideal, ultimate meaning of this rule.

In general, scholars dealing with EU multilingualism ${ }^{33}$ have always emphasized that EU translation is not only an essential technique integrated in the

29 EEC Council: Regulation No 1, April 15th, 1958, determining the languages to be used by the European Economic Community, Official Journal 017, 06/10/1958 P. 0385-0386

30 Reg. 1/1958, art. 4 "Regulations and other documents of general application shall be drafted in all the official languages".

31 See on this point: Anne Wagner and Jean-Claude, "Materializing Notions, Concepts and Language into Another Linguistic Framework", International Journal for the Semiotic of Law, Revue Internationale de Sémiotique Juridique, Vol. 26 (2013), 739.

32 One example is the concept "regulation" - "règelement"- "Verordnung" (etc.).

33 Susan Šarčević, New Approach to Legal Translation (The Hague: Kluwer Law International, 1997). 
drafting process, ${ }^{34}$ but also a harmonization tool reducing the multi-language complexity to a common meaning. ${ }^{35}$ It is by now clear in the scientific environment that EU legal language is a specific field of legal translation, that calls for thorough studies in this field too. ${ }^{36}$

In comparative law studies particularly, the EU legal language has become a research field of growing importance and the initial limited understanding of the nature of this legal language has been gradually improved by a specialized domain of scientific contributions.

\subsection{Multilingual Law Studies}

This brief survey of the main monographs on EU law and language does not include studies on law and language in general, even if also related to legal translation (for all Malmkjær and Windle 2011; Mattila 2006), or specifically on legal translation (Tiersma and Solan 2016) or dealing with the relation between language and law in general (for all Freeman and Smith 2013). This is not because these studies are of no interest for European jurists (consider the well-known work of Šarčević 1997), but to limit the area of analysis to studies dedicated specifically to European law multilingualism. These studies were anticipated by some pioneering research in the field of law and multilingualism, like for instance the volume edited by Rodolfo Sacco and Luca Castellani in 1999 "Les multiples langues du droit européen uniforme". 37

One of the very first monographs is the German language analysis of the problems of interpretation of - what at that time was still "Community law" - by Isabel Schübel-Pfister (2004). ${ }^{38}$ That work was soon followed by Richard

34 Colin D. Robertson, "EU Legislative texts and Translation”, in The Ashgate handbook on legal translation, eds. L. Cheng, K.K. Sin, and A. Wagner, (Routledge, Abingdon Oxon (UK), New York (USA), 2014), 159-176.

35 See Sieglinde E. Pommer, "Interpreting Multilingual EU Law: What is the Role of Legal Translation?”, European Review of Private Law (2012), 1254, who evokes translation as the metalanguage of EU legal integration.

36 Susan Šarčević, Language and Culture in EU Law: Multidisciplinary Perspectives (Abingdon Oxon (UK), New York (USA): Routledge, 2016).

37 Sacco R, Castellani L., Les multiples langues du droit européen uniforme, Turin: Harmattan, 1999.

38 Isabel Schübel-Pfister, Sprache und Gemeinschaftsrecht - Die Auslegung der Mehrsprachig verbindlichen Rechtstexte durch der Europäischen Gerichtshof (Berlin: Duncker \& Humblot, 2004). 
Creech's ${ }^{39}$ contribution on the language regime of Europe (2005). A few years later, Mattias Derlén's essay (2007 and 2009) ${ }^{40}$ focused on the attitude towards the multilingual interpretation of Community law of the national courts of Denmark, England, and Germany. The interest in EU multilingual law in dedicated volumes returned in 2013, thanks to Elina Paunio's book on the impact of multilingualism on the judicial reasoning of the Court of Justice of the European Union. ${ }^{41}$ "EU Language and Law" by Stephaan Van der Jeught (2015) followed, as an opus having a wider aim of analysis and focusing on the regulation of languages. ${ }^{42} \mathrm{~A}$ year later was the time of Colin Robertson's interdisciplinary work "Multilingual Law. A Framework of Understanding" $(2016)^{43}$ that was addressed especially to EU lawyer-linguists and academics. The recent contribution of Baaij (2018) ${ }^{44}$ analyzes the specific difficulties of interpreting EU law uniformly from the point of view of translation, in order to address proposals and policy advice.

As one can guess, the object of interest of the above-mentioned studies is not identical and every work studies a different aspect of European legal multilingualism. Accordingly, Schübel-Pfister's work focuses on the problems of interpretation of Community law with particular attention to the case law of the CJEU on conflicting language versions. There the national level is analyzed from the point of view of the case law of the Court providing the duty of national judges to compare all different language versions of EU legislation. According to the author's analysis, this case law is qualified as inconsistent and incompatible with the general principles of Community law. In her research outcome, Schübel-Pfister then suggested a model in which the duty of national courts to go through a

39 Richard L. Creech, Law and Language in the European Union: The Paradox of a Babel "United in Diversity" (Amsterdam: Europa Law Publishing, 2005).

40 Mattias Derlén, A Castle in the Air: The Complexity of the Multilingual Interpretation of European Community Law, (Umeå (Sweden): Umeå Studies in Law, 2007); Mattias Derlén, Multilingual Interpretation of European Community Law (The Hague, New York: Kluwer Law International, 2009).

41 Elina Paunio, Legal certainty in multilingual EU law. Language, discourse and reasoning at the European Court of Justice (Farnham, Surrey (UK): Ashgate, 2013). In the same period of time, a book written by the author of this Chapter was meant to introduce Italian academics and professionals to EU legal language: Elena Ioriatti, Interpretazione comparante e multilinguismo europeo (Padua: Cedam, 2013).

42 Stefaan Van Der Jeught, EU Language and Law, (Groningen (NL): Europa Law Publishing, 2015).

43 Colin D. Robertson, Multilingual Law. A Framework for analysis and understanding, (Abingdon Oxon (UK), New York (USA): Routledge, 2016a).

44 C.J.W. (Jaap) Baaij, Legal Integration and Language Diversity. Rethinking translation in EU lawmaking (New York: Oxford Studies in Language and Law, 2018). 
language comparison of EU legal concepts should be graduated accordingly with the area of Community law and the ratio legis of each specific provision.

In his well-known work, Derlén focused on how the institutional mandate to national courts to compare the different language versions in interpreting European community law (EC law) was actually performed. After examining an impressive number of national decisions of German, Danish, and English courts, the author demonstrated that, at the time of his research, the multilingual character of EC law had a limited impact in national courts, as frequently EC norm was interpreted without the support of any foreign language version. The study also suggests a reform of the multilingual interpretation of EC law, where only few languages, preferably English and French, should be qualified as the only mandatory consultation languages by national courts to reach a uniform interpretation and application of EU law. ${ }^{45}$

Creech and Van der Jeught do not concentrate efforts specifically on the interpretation of EU multilingual law. However, their interesting research outcomes do contribute to the problem of determining the language meaning of EU law, because policies on multilingualism are often interlocking reasons behind an EU concept and neologism choice. Creech observes EU law from the point of view of language regulation - linguistic regimes of EU organs, case law of the CJEU, EU programs of legal education, language regulation in the Member States, EU language rights - in the light of the EU policy. He concludes by arguing that language is primarily understood and regulated by the EU as an economic affair, a medium through which commerce is conducted. ${ }^{46}$ Van der Jeught analyses the same areas and underlines a fragmented EU and national language policy approach, in which the different levels sometimes hamper EU integration itself. As a conclusion, the author calls for the adoption of one single vehicular language of communication in the EU, combined with equal status of all others in specific areas of EU law. ${ }^{47}$

Similarly, in order to favor a uniform interpretation and application of EU law, Baaij places emphasis on the role of English as a lingua franca. By clearly observing the reality of the EU multilingual environment, the author suggests the English language version as the original and only authentic legislative Englishbased text, according to a source-oriented technique of EU translation illustrated in details.

45 Mattias Derlén, A Castle in the Air: The Complexity of the Multilingual Interpretation of European Community Law, (Umeå (Sweden): Umeå Studies in Law, 2007).

46 Richard L. Creech, Law and Language in the European Union: The Paradox of a Babel "United in Diversity" (Amsterdam: Europa Law Publishing, 2005), 157-158.

47 Stefaan Van Der Jeught, EU Language and Law, (Groningen (NL): Europa Law Publishing, 2015), 272-274. See also Moretéau, 1999. 
From a different perspective, Paunio's main aim is to analyze the concept of legal certainty in multilingual EU law, qualified as predictability and acceptability, with particular attention to the uncertainty surrounding EU multilingual legislation and the consequences of multilingualism on the judicial reasoning of the CJEU. The intensive and extensive idea accompanying every chapter of the book suggests a conception of legal certainty not based on objectivity or the immutability of the language, but on a "discursive legal certainty," based on acceptability of judicial decision-making and dialogue within the EU legal community.

Focused on interdisciplinarity, the insight of Robertson's volume on multilingual law specifically relates to different disciplines - law, language, semiotics, translation, technology - in connection with multilingualism, and so, by extension, to interdisciplinarity. As such, the book is an extensive source of inspiration and information.

The results of these monographic studies are supplemented by collective works. ${ }^{48}$ In addition, there are a number of dedicated chapters or parts of volumes on European multilingualism, ${ }^{49}$ as well as contributions of single authors of undoubted value, some of which are quoted in this article.

Notwithstanding this overview of the literature on EU multilingual law is not exhaustive, it becomes clear that not only theoretical research has taken out the nature of multilingual texts of European provisions from obscurity, but that there is a growing tendency to think in terms of how important language is in EU law studies. As noted already, in general, the majority of the studies on EU law multilingualism have their focus of attention on the EU level, mainly analysing the environment of multilingual translation or the judicial reasoning and case law of the CJEU.

However, there is also a somewhat less visible process at work, going on in the community of jurists and professionals who are involved in the application of EU law in the Member States, as well as in national legislation, enforcing or related to EU law sources. In this regard, appreciation goes to those scholars who urge for more attention on the normative forces grounding the practices of law in Europe. ${ }^{50}$

48 Barbara Pozzo, Valentina Jacometti, V. Multilingualism and the Harmonisation of European Law (The Hague: Kluwer law International, 2006). Antonio Gambaro, A. "Interpretation of Multilingual Legislative Texts”, Electronic Journal of Comparative law, vol. 11.3: 1-20, 2007. Susan Šarčević, S. Language and Culture in EU Law: Multidisciplinary Perspectives (Abingdon Oxon (UK), New York (USA): Routledge, 2016).

49 Peter M. Tiersma, and Laurence M. Solan, The Oxford Handbook of Language and Law (Oxford: Oxford University Press, 2012), Lin Cheng, King K. Sin, \& Anne Wagner, (eds.), The Ashgate Handbook on Legal Translation (Abingdon Oxon, New York: Routledge, 2014).

50 Michele Graziadei, "Law, Language and Multilingualism in Europe: the Call for a New Legal Culture”, In Language and Culture in EU Law. Multidisciplinary Perspectives, edited by S. Šarčević, 17-32 (Abingdon Oxon (UK), New York (USA): Routledge 2016): 29. 
Some of these scholars have gradually disclosed delicate technical aspects of EU multilingual law, or proposed pragmatic solutions, like the importance of maintaining a constant dialogue among the different actors involved in the legislative and judicial process. ${ }^{51}$ In this regard, Pommer's work is particular in a field where research is mostly concentrated on the supranational level. ${ }^{52}$ The author proposes to include translation among the criteria for interpretation to be followed by national courts. Although difficult to trace within the process of EU legal drafting, Pommer underlines that translation should be a necessary stage of EU law interpretation and application by national courts. Translation as a criterion of interpretation would methodologically justify text reconciliation, as a way of expressing the thought that can be faithful to a text without being entirely literal.

Furthermore, a recent contribution by Dérlen ${ }^{53}$ underlines a dichotomy on the EU institutional level. That dichotomy takes place between "full multilingualism," which prevails in legislation providing equal authority of each official language (single meaning approach) and "limited multilingualism" in CJEU case law, where judgments are authentic only in the language of the case (single text approach). According to the author, this is the uncertainty in which EU national courts are situated and that, if not solved, will continue to affect uniform interpretation of EU legislation.

Thus, within the scientific community the idea that the analysis of EU legal language requires the same observation of the national level is also slowly gaining space.

It is at this point that the contribution of this article begins, arguing attention to this dimension, as well as to interdisciplinarity.

Firstly, if all questions of interpretation and application of EU terminology were themselves considered questions to be solved at the EU supranational level, the experience, contributions and even role that national courts and legislators have accumulated in more than nearly seventy years of activity would not be taken into consideration as component of the EU legal language.

Secondly, even if some of the views in the scientific community are interdisciplinary in nature, thanks to the different background of the authors considered above, it would be a misunderstanding to believe that this multidisciplinary cooperation could be carried out only as a scientific dialogue. The hybrid

51 Jan Engberg, “Autonomous EU Concepts - Fact or Fiction?”, in Language and Culture in EU Law: Multidisciplinary Perspectives, ed. S. Šarčević, (Abingdon Oxon (UK), New York (USA): Routledge, 2016), 169; Silvia Ferreri,. "Loyal to Different Exclusive Masters: Language Consistency at the National and Supranational Level”, Statute Law Review (2016): 181.

52 Sieglinde E. Pommer, “Interpreting Multilingual EU Law: What is the Role of Legal Translation?", European Review of Private Law (2012).

53 Mattias Derlén, “Multilingual Interpretation of European Community Law”(The Hague, New York: Kluwer Law International, 2009), 53. 
characters of EU law, juridical and linguistic, requires the involvements of methodologies of different disciplines in researches which go beyond the strictly juridical substance of EU law. Particularly, this article attempts to underline that if all questions are qualified as presuming answers only in juridical terms, the aspect of EU law being framed and structured by multilingualism and so by a linguistic element would be underestimated.

\subsection{Interdisciplinary Approaches}

From the above, it is clear that despite the ongoing developments in specialized EU multilingualism studies, the European legal language is still in want of responses with regard to its own characteristics as to the application and interpretation in the member States. Yet, acknowledging this stage of comparative law research should be perceived not as a limit, but as a point of departure for new fields of investigation in the fascinating world of modern legal studies, which still remains in a state of evolution. Not coincidentally, in order to widen scientific observation, quite a number of scholars have pointed out the need for a more in depth interdisciplinary approach, by analyzing semantic, legal and linguistic aspects of such legal language. ${ }^{54}$ This field of literature underlines that a strict juridical and substantial approach to each single concept expressed in each language version does obscure to the interpreter a more general, elastic, and formal overview of this unique phenomenon. ${ }^{55}$ Semiotics, which is the study of signs, ${ }^{56}$ is suggested as a new perspective to improve the understanding of the linguistic nature of EU language. In this field of research, EU law is studied from the semiotic point of view and so observed as a system of signs ${ }^{57}$ and a horizontal meta-juridical law. ${ }^{58}$ From this perspective, EU legal terms form a horizontal system of linguistic signs, in which each one formally and ideally bears the same legal concept as containing an inter-lingual synonym. It is up to the form to give the same meaning to a new

54 Colin D. Robertson, Multilingual Law. A Framework for analysis and understanding, (Abingdon Oxon (UK), New York (USA): Routledge, 2016a), p. 172.

55 Le Cheng, Winnie Cheng and Sin King Kui, "Revisiting legal terms: A semiotic perspective". Semiotica (202) (2014): 179.

56 Semiotics emerged as an independent science at the beginning of the twentieth century with the studies of, among others, Charles Sander Pierce and Ferdinand de Saussure.

57 Colin D. Robertson, Multilingual Law. A Framework for analysis and understanding, (Abingdon Oxon (UK), New York (USA): Routledge, 2016a), 144.

58 Joseph G. Turi, “Le droit linguistique et les droits linguistiques”, Les Cahiers de droit (1990): 642. 
multilingual reality expressed in all official languages. ${ }^{59}$ Owing to its vast composition of neologisms, EU law represents an ideal tool for semiotic observation. ${ }^{60}$ Composed by norms and words expressed in all the official, different language versions, but representing a unique linguistic item of a new term $^{61}$ (linguistic form of the signifier or signifier of the linguistic sign), EU concepts acquire a meta-juridical feature so as to horizontally transmit the same content in all linguistic versions. ${ }^{62}$ This approach favours an overall and neutral observation of EU legal language, free from the technical details and legal meanings that are inevitably present in each language version. This terminological equation resulted in comparative law studies that are starting to look at multilingualism concepts as linguistic signs. ${ }^{63}$ In general, invoking the methods of linguistic sciences in legal analysis involves the danger of reading more into the linguistic term than what it stands for within their legal effects. As will be seen below, this is not the case when one of the legal semiotics instruments - the meta-language - is utilized in comparative law analysis as a conceptual tool. Framing EU norms is a linguistic formulation to be completed by a second level of norms on the national level. This semantic exteriorization of EU legislation highlights the role of the national formants in attributing meaning to EU neologisms.

59 Colin D. Robertson, "LSP and EU Legal Language”, in Reconceptualizing LSP, eds. C. Heine and J. Engber, 1-7. Online proceedings of the XVII European LSP Symposium, 3.

60 Joseph G. Turi, “Le droit linguistique et les droits linguistiques”, Les Cahiers de droit (1990): 641.

61 In the background, clearly, the theory of de Saussure (1916), who describes language features referring to two well-known expressions: the signifier and the signified, which compose the linguistic sign. In the words of Louis Hjelmslev (1928) these two terms are renamed respectively expression and content. Therefore, the linguistic sign is composed by a signifier/expression and a signified/content, which separate form from substance.

62 Gérard Cornu, Linguistique juridique (Paris: Montchrestien, 2005).

63 Michele Graziadei, "Law, Language and Multilingualism in Europe: the Call for a New Legal Culture”, in Language and Culture in EU Law: Multidisciplinary Perspectives, ed. S. Šarčević (Abingdon Oxon (UK), New York (USA): Routledge 2016), 28; Susan Šarčević, Language and Culture in EU Law: Multidisciplinary Perspectives, (Abingdon Oxon (UK), New York (USA): Routledge 2016), 185; Colin D. Robertson, Multilingual Law. A Framework for analysis and understanding, (Abingdon Oxon (UK), New York (USA): Routledge, 2016a), 129 ff. and Colin D. Robertson, C.D., "EU Multilingual Law: Interfaces of Law, Language and Culture”, in Language and Culture in EU Law: Multidisciplinary Perspectives,ed. S. Šarčević, (Abingdon Oxon (UK), New York (USA): Routledge, 2016b), 33 ff.; and Elena Ioriatti, "Formulation of rights and European legal discourse: any theory behind it?”, International Journal of Legal discourse (2016): 375. 


\section{Multilingual Law: The National Level}

\subsection{The Semiotics Perspective}

Let us pause and consider what EU neologisms currently mean for the national interpreter. It might be useful first to recall that notwithstanding the development of some relevant areas of European legislation (i.e. consumer law) towards maximum harmonization and a specific legal language gradually surfacing, no one can still advocate the existence of a comprehensive conceptual background against which to interpret the EU legislation, even in terms of a common culture or general system of referents. Most multilingual concept formulations are an approximation of the ideal expression of an EU norm that pre-exists and of its transferability into a linguistic framework, common to all official language versions. Thus, when it comes to the interpretation of EU concepts, national interpreters - lawyers, judges, academics and jurists in general - run the risk of "not seeing the forest for the trees" when focusing on the single concept of their own national language version.

Again, seen through semiotic lenses, EU language acquires a more uniform dimension. This somehow linguistically and terminologically justifies the institutional mandate of equal authenticity of all language versions. In this regard, among the instruments available in semiotics, "meta-language" has the goal of determining the layers of meaning of a language that make up a meaningful whole. ${ }^{64}$ Here, the branch of semiotics dealing with the language of the law is of interest in multilingual studies where the "meta-language" (also described as "a (legal) language speaking of another legal language") ${ }^{65}$ is used to analyze different levels of a law discourse. For instance, a hierarchic overlap of norms, like constitutional norms, establishing certain principles as language boundaries (meta-language), which ordinary legislation (statutes) formulation must consider; similarly, ordinary legislation is composed by words that guide the application of its norms in court decisions. The latter is a typical example of meta-legal language: the linguistic formulation of a legislative norm prescribing a specific content of the meaning that a different norm must have, for example, an article of the civil code and the court judgement that applies that article.

The semiotic concept of meta-language is a useful observation point to study the relation between the legal language of the European legislator and legal

64 Bengü Batu, “An Overview of the Field of Semiotics”, Published by Elsevier Ltd: 464-469 (2012), 468, also for an agile overview of the different fields and methods of semiotics. 65 Mario Jori and Anna Pintore, Filosofia del diritto (Turin: Giappichelli, 2014), 179 ff. 
language of national courts that interpret and apply such legislation. ${ }^{66}$ From this semiotic angle, EU law could be observed as a meta-language, as the norms of primary law contained in the treaties prescribe part of the content of secondary legislation (meta-norms in semantic terms), which in turn prescribe in linguistic semantic terms part of the content of last level norms: court decisions.

As already noted above, suggesting an interdisciplinary approach in this chapter means relying on methods of science other than comparative law - semiotics, in this case - in order to proceed in the analysis of the specific features of EU legal language. Thus, as noted by Robertson, thinking in terms of semiotics "does not solve any problems, but provides a conceptual tool to help think about a given problem". ${ }^{67}$

66 Reference to semiotics at the EU level was also made by Klimas and Vaiciukaite (Tadas Klimas, and Jurate Vaiciukaite, "Interpretation of European Union Multilingual Law", International Journal of Baltic Law, No. 3, 2005: 1-13) by referring the meta-language to the case law of the Court of Justice of the EU of the European Union, in an article analyzing the interpretative approach of the Court to language discrepancies in various versions of EU legislation. According to the Authors, when the CJEU seeks to find the law of the European Union among different language versions, not confining itself to any or even all of the texts, but searching for the true legislative intent of a given provision, the law transcends language and a case law meta-language is in the process of development. De Groot (Gérard René De Groot, "Das Übersetzen juristischer Terminologie”, in Recht und Übersetzen, edited by G.R. De Groot and R. Schulze. Baden-Baden (D): Nomos, 1999) too advocated the development of a legal meta-language in order to make a legal language uniform at the international level, by conveying legal terms that are defined by national law, in which a complete equivalence between the terms of two legal systems can only be attained if both legal languages refer to the same legal system, positing an acceptable equivalence between two legal systems and not two languages (literally reported: Marcus Galdia, "Comparative law and legal translation”. The European Legal Forum (E) 1-2003, 2003: 2). National courts case law interpreting national legislation in conformity with EU law was defined "meta-rule" by Hannes Rösler, "Interpretation of EU law”, in: Interpreting EU law, J. Basedow Basedow, K. J. Hopt, Reinhard (eds.), Max Planck Encyclopedia of European Law, Vol. 2 (Oxford, 2012), 980. Another example is the model for technical translation as the translation into a meta-language: Galdia suggested meta-language as the universal descriptive language for the propositional content of legal texts for which the framework for developing is found in comparative law (Marcus Galdia, “Comparative law and legal translation”. The European Legal Forum (E) 1-2003, 2003: 3). References to EU languages as a meta-language also in Elena Ioriatti, Interpretazione comparante $e$ multilinguismo europeo. (Padua: Cedam, 2013), 3, 76, 138. See also René De Groot, "Problems of legal translation from the point of view of a comparative lawyer”. In Translation, our future/La traduction, notre avenir, edited by P. Nekeman, 407-421. Proceedings of the XIth Congress of FIT, Maastricht, 1988.

67 Colin D. Robertson, Multilingual Law. A Framework for analysis and understanding, (Abingdon Oxon (UK), New York (USA): Routledge, 2016a), 131. 
In the case of EU law, the problem is attributing European legal meaning to EU concepts, and favouring their uniform application at the national level. The conceptual tool is the qualification of EU secondary law as a meta-language.

This point of observation allows us to consider the meta-norms and the metaconcepts composing EU directives and regulations as linguistic formulations prescribing a specific juridical content that has to be completed by a second level of norms or concepts, those enacted (national legislation enforcing EU law) or formulated (national case law) at the national level.

In this regard, the thesis addressed in this article, and based on actual observation, is that national case law, and national legal formants in general, do actually contribute to the meaning of EU concepts. In order to highlight this aspect of the reality of the EU legal process, observing EU legislation as a "meta-language," composed by "meta-norms" and so "meta-concepts" proved to be useful as it constructs a mental image that helps to objectively observe the phenomenon.

\subsection{EU Legal Language in the Courts}

A common belief in the field of interpretation and application of EU law at the national level is that judges not only are hesitant in handling EU concepts as "European" and "autonomous," 68 but that national courts limit themselves to a mere application of norms and words of the European legislative texts, without contributing to elaborate their meaning. For a number of years, this timid attitude of national jurists was effectively at the basis of the interpretation of EU norms, probably favoured by the implicit belief that European concepts should be "gently" applied without "overstepping" the supranational norm, with no expectations of any possible contribution to the legal meanings of EU norms.

This atmosphere - probably also due to the relatively recent existence of the EU legal system - only remotely recalls the twentieth century debate on the "objective" or "subjective meaning" of norms. As already explained at the beginning of this article, by simplifying a much more complex question, in that period the core of the issue was: does written norm have an "objective” meaning per se, or is this meaning also the result of the contribution of the interpreter (judge or legal scholar)? Thus, to be visualized in its real flow, this method of interpretation of EU norms must be seen against the background of that current of thought

68 This principle was ruled almost 40 years ago by the European Court of Justice of the EU in the well- known "Cilfit” case (Case 283/81 - Srl Cilfit and Lanificio di Gavardo (SpA) v Ministry of Health) posing a milestone for the development of the EU legal language, completely freeing the EU legal concept from the national environment as independent and autonomous. 
which, in its development since the mid last century, has qualified the norm - the normative legislative declaration - not as composed by purely objective elements, but also by the subjective elements and preference of the judges, as a basis for their decision. As already noted, that openness to the role of the interpreters in attributing meaning to a norm, the words of which do not address any objective message, implies that this meaning largely depends on judges' cultural background and individual persuasions.

One of the things that stands out nowadays is the awareness of national interpreters that EU legislation and its normative declaration is not to be read according to their own national context. In this regard, by contributing to European projects involving notaries, judges, land registry civil servants, and academics, the author of this article has had the privilege to investigate some of the developments of EU norms and concepts in the national environments, and to observe these same environments.

This modest survey demonstrates that the initial sense of disorientation for the community of professionals towards the legislation formulated in Brussels is almost overcome. EU law is no longer a "stranger" law, but part of the professional life of people in Europe. Particularly, national judges have developed the right sensibility and the capacity to recognize EU concepts as autonomous (as provided by the case law of the CJEU) regardless of the distance from their own national legal culture. However, an aspect that is particularly relevant is that national judges handle EU law not by simply providing pragmatic solutions for the specific matter at stake, but by formulating norms with the awareness of contributing to ascribing a meaning to EU law. Strangely enough, national interpreters seem to have only recently metabolized the role of "community judges." ${ }^{69}$ Nevertheless, the fact that judges - even if not of the common law - are fully aware that their judgments on EU law do not merely decide individual cases, but also declare abstract statements which will guide future cases, does not sufficiently explain this growing constructive and respectful attitude towards EU norms.

Even if generalizations must be handled with care, various symptoms of a uniform and supranational attitude in the interpretation of domestic courts are emerging globally, together with the loss of a dominant position of the syllogistic model. ${ }^{70}$ In this framework, the same hermeneutical criteria elaborated by the CJEU, particularly

69 The same title of a work dealing with EU legal language recalls this situation as one of the "Paradoxes of European Legal Integration" (Hanne Petersen, Anne Lise Kjær, Mikael Rask Madsen, Paradoxes of European Legal Integration (Aldershot (UK), Burlington (USA): Ashgate 2008). 70 Bartosz Wojciechowski, "Discourse Ethics as a Basis of Application of EU Law”, in Interpretation of Law in a Global World: From Particularism to an Universal Approach, J. Jemielniak \& P. Mikłaszewicz (eds.) (Berlin, Heidelberg: Springer Verlag, 2010a), 53. 
the teleological one, might have indirectly assigned a constructive role to national courts together with specifically European tools for interpretation.

There are, however, a number of crucial implications when acknowledging that national interpreters do contribute to the meaning of EU norms and concepts. Indeed, on an institutional basis, this is a natural consequence of the role that the same EU form of government has attributed to national courts, as the interpreters of EU secondary law in the Member States.

Needless to recall that the creation of the EU has involved the establishment of a new legal order, since its sources have also the function of harmonizing national law, in specific fields, and furthermore of developing a coherent supranational legal system, according to the aims of the treaties. As EU law sources have direct effect in the Member States, or are enforced through internal national legislation, national courts are attributed the institutional duty of application and interpretation of EU law, as well as its development. It is precisely the activity of interpretation within the supranational legal system that contributes to identifying and determining the development of the norms and concepts regarding European legal sources. The case law of national judges, in fact, represents the main reference point to establish the meaning of a national norm, having European origin.

The enormous importance of the continued influence of national courts makes it even superfluous to quote the authors who qualify the EU legislation and the national courts case law as a "shared unique system of rules of a polycentric institution," producing norms according to a gradual development of institutional interaction. ${ }^{71}$ In other words, it is the institutional structure of the EU itself that is attributing jurisdiction on EU law to national courts, whose judges thus become the EU "ordinary judges and so the interpreters of EU law, carrying out this institutional task exactly as it is in their own legal system."72 Also for this reason, observation of national case law on EU legislation should become more and more a sensitive issue of mainstream research for comparatists too. Indeed, comparison recognizes solutions to legal issues - and so "rules" - as formants. ${ }^{73}$ The wellknown definition formant - again, borrowed from phonetics - denominates the

71 Ana Bobic, “The shared system of rules in a polycentric European Union”, in Polycentricity in the European Union, eds. J. Van Zeben and A. Bobic (Cambridge: Cambridge University Press 2019), 143 and 161. The design of the EU legal process as a polycentric system of norms, implies that not only national legislators and judges contribute to shape the legal meaning of the EU linguistic signs, but de facto also notaries, public servants and academics too.

72 Michel Mahieu, "L'interprétation du droit communautaire", in L'interprétation de droit. Approche pluridisciplinaire, ed. Van de Kerchove (dir.) (Brussels: Presses de l'Université SaintLouis, 2019), p. 349-383.

73 Rodolfo Sacco, "Legal Formants: A dynamic Approach to comparative Law", The American Journal of Comparative Law, XXXIX (1991), $21 \mathrm{ff}$. 
rules formulated by the legislator, decided by courts and elaborated in scholarly works as the result of actual observation of the elements at work in a given legal system. Within the context of the EU legal system, formants - national case law, legislation enforcing EU directives, doctrine on EU law - are also components of EU law ${ }^{74}$ and do contribute to the construction of meanings of its conceptual structure. In this context, the following exercise, based on a real case study, is the result of the observation of some of these elements at work in some of the EU legal systems.

\section{EU Meta-concepts and National Formants: An Exercise}

The suggested analysis is the EU Framework Directive 2008/98 on waste, enacted as part of the action of the EU towards environment protection. The recent version (2018) of the Framework Directive (hereinafter "Directive on Waste") is particularly worthy of attention since in the definitions of art. 3, at point 6 , it deals with the concept "possession," 75 an abstract, relevant term in the area of private law of the Member States.

In order to facilitate the explanation, the following tables serve as a token outline to assemble information on different legal systems with regard to how "possession" is regulated in some national legislations (Table 1) and in art. 3 of the Directive on Waste (Tables 2 and 3).

Table 1: The national concept in some EU Member States.

\begin{tabular}{llllll}
\hline Bulgaria & Italy & Germany & Austria & Belgium & France \\
$\downarrow$ & $\downarrow$ & $\downarrow$ & $\downarrow$ & $\downarrow$ & $\downarrow$ \\
владение & possesso & Besitz & Besitz & possession & possession \\
\hline
\end{tabular}

74 See for all John Bell and David Ibbetson, "European Legal Development. The case of Tort”, (Cambridge: Cambridge University Press. Comparative studies in the Development of the Law of Tort in Europe), vol. 9, xii + 213 (2012/2014): 3.

75 Please note that in the present case study the English version of the Directive on Waste is reported and not the concept of "possession" of the English legal systems: because of the consequences of Brexit and England not being part of the European Union anymore, the English legal system is not included in this exercise. As a consequence, the word "possession" is meant to be intended as A) the word present in the Directive on Waste, art. 3: definition, point 6 B) The word in the language of this article referring to the other definitions. 
Table 1 lists the national concepts corresponding to the word "possession" in some EU Member States. In all these legal systems, with the sole exception of Germany, private law distinguishes between "possession" and "holding/ detention". ${ }^{76}$

Particularly, the concepts "Besitz (Austria), possesso (Italy), владение (Bulgaria), possession (Belgium and France)” means "material control on a good/ property" with animus domini.

Differently, the meaning of the concepts "Innehabung (Austria), detenzione (Italy), държане (Bulgaria), deténtion (Belgium and France) is "material control on the good without animus domini”.

In Germany, differently from Austria" 77 the word "Besitz" does not include the requirement of the animus domini. ${ }^{78}$ Further, German law has not adopted the distinction between possession and holding/detention. The wide notion of Besitz covers both the situation in which the possessor holds the good for himself (Eigenbesitz) and the situation that a person holds a good (property) for another (Fremdbesitz) ${ }^{79}$ and so regardless of the requirement of animus domini.

The analysis calls for an exploration of the key notion "possession" in the Directive on Waste. Let us therefore observe the key concept "possession" in art. 3, n. 6. That concept is necessary since it is used in the definition of "waste holder." Here is the English version: "Art. 3 Definition. n. 6. 'waste holder' means the waste producer or the natural or legal person who is in possession of the waste." Languages take different approaches. For example, French relies on the word

76 The distinction is regulated in the civil codes of Austria, Belgium, France, and Italy; in legislation in Bulgaria: Ownership Act, 1951 and amendments (Last amendments: February 2020).

77 On the different meaning of "Besitz" in the German legal language of Germany compared to the ones of Austria, and Switzerland see: Rodolfo Sacco, "Legal Formants: A dynamic Approach to comparative Law”, The American Journal of Comparative Law, XXXIX (1991), 11-12.

$78 \S 854$ BGB Acquisition of Possession. (1) Possession of a thing is acquired by obtaining actual control over the thing.

79 Mary-Rose McGuire, "National Report on Germany", in National Reports on the Transfer of Movables in Europe, eds. W. Faber and B. Lurger, Volume 3, 1-192, (Munich: Sellier, European law publishers GmbH 2011): p. 45. Furthermore, the distinction between Innehabung and Bezits in German Law may be derived from a comparison of $\S 872$ with $\S 854$. $\S 872$ which provides that a person is called a proprietary possessor (Eigenbesitzer) if he possesses the thing as belonging to him, therefore with an animus rem sibi habendi. From this provision it can be inferred that the intention with which a person holds physical control is of significance. Case law contends for a very general animus possidendi, which as a rule need not be further specified and will be presumed to exist and the majority of legal doctrine demands an indication of the intention to acquire possession (Besitzbegründungswillen). McGuire, p. 45 and 46. 
"possession"80; while German on the word "Besitz"81 Furthermore, Italian relies on the word "possesso" 82 Only Bulgarian, as we will see below, goes in a different direction. $^{83}$

Table 2: The EU meta-concept.

\begin{tabular}{llll}
\hline Bulgarian & Italian & German & French \\
$\downarrow$ & $\downarrow$ & $\downarrow$ & $\downarrow$ \\
$\mathrm{X}$ & possesso & Besitz & possession \\
\hline
\end{tabular}

All the official language versions of the Member States under analysis, with the only exception of Bulgaria, have chosen to rely on the same word used in their national systems to qualify the key concept "possession."

The EU meta-concept returns to the main stage at this point. Notwithstanding almost all of the language versions, when qualifying the key concept on the national word in the Directive on Waste, it is important to be reminded that these words are, at the same time, EU meta-concepts and neologisms, bearing an autonomous European meaning. It is well known that norms are not always strictly linked to their language expression, as different operative rules can be found in the formants, regardless of whether formal definitions are similar.

In the case under analysis, it was to the national formants to uncover the autonomous European meaning. In Italy a decision of an Administrative court ${ }^{84}$ (2018), ruling on the meaning of the key concept "possesso" of the Italian version of the Directive on Waste, provided as follows: "The Italian notion of 'possesso' and 'animus possidendi' is not applicable as the cost of waste provided in the EU directive is not grounded on the intention of the holder/possessor to behave as an owner (with animus possidendi), but on the duty of care owed by him." ${ }^{85}$ According to the Italian courts, the European concept of "possesso," differently to the Italian synonym, does not require the presence of the animus domini, but simply of a material control on the good (waste).

80 «détenteur de déchets»: le producteur des déchets ou la personne physique ou morale qui a les déchets en sa possession.

81 „Abfallbesitzer“den Erzeuger der Abfälle oder die natürliche oder juristische Person, in deren Besitz sich die Abfälle befinden.

82 «detentore di rifiuti» il produttore dei rifiuti o la persona fisica o giuridica che ne è in possesso. 83 „притежател на отпадъци“ е причинителят на отпадъци или физическото или юридическото лице, което има фактическа власт върху отпадъците.

84 Tribunale Amministrativo Regionale Brescia, 29/01/2018.

85 Tribunale Amministrativo Regionale Brescia, 29/01/2018. 
Let us try to add other formants to the same exercise. In Belgium the national decree enforcing the Directive on Waste provides "the possessor is also the person who has not the physical possession of the waste” (qui n'ont pas la possession physique des déchets). In Bulgaria the same norm of the Directive on Waste has been formulated in a way that excluded the animus possidendi to be qualified "waste holder:" 'waste holder' means the producer of the waste or the natural or legal person having actual power over the waste. ${ }^{86}$

The results of this exercise invite for further reflection. As noted above, the Italian decision, the Belgian legislation enforcing the Directive on Waste, and the Bulgarian language version of that Directive attribute a meaning to the word "possession" that is different from the one attached to the same word at the national level. Particularly, in these language versions, the concept "possession" does not presume the presence of the animus domini in the intention of the person having the material control on the waste. Furthermore, in the example at issue, the Belgian decree and the same Bulgarian version do confirm the same EU meaning as the Italian case law formant. As noted above, national case law seems to be more than active in EU meaning construction. Yet, something more should be underlined: this exercise demonstrates (Table 3) that EU meta-concepts acquire meaning once they are entered into the judicial, hermeneutical process, and turn into final, consolidated concepts after being interpreted, applied, and qualified in court decisions. Other national formants (e.g., national legislation enforcing EU law) also contribute to this consolidation process.

Table 3: The consolidated EU concept.

\begin{tabular}{lcll}
\hline Bulgaria & Italy & Germany/Austria & France/Belgium \\
$\downarrow$ & $\downarrow$ & $\downarrow$ & $\downarrow$ \\
власт & possesso & Besitz & possession \\
& material control in general (regardless of animus domini) & \\
& $\uparrow \uparrow \uparrow \uparrow \uparrow \uparrow \uparrow \uparrow \uparrow \uparrow \uparrow \uparrow \uparrow \uparrow \uparrow \uparrow \uparrow \uparrow \uparrow \uparrow \uparrow \uparrow \uparrow \uparrow$ & \\
& National formants & \\
\hline
\end{tabular}

This example is meant to suggest that multilingual legislative texts can potentially be uniformly interpreted and constructed when operational rules uncovered in some national formants contribute to assigning meaning to an EU concept. In fact, the qualification of the concept "possession" in the Directive on Waste as "EU meta - concept" and the interpretation according to the EU

86 Emphasis added. Unofficial translation. The official text reads in Bulgarian: „притежател на отпадъци“е причинителят на отпадъци или физическото или юридическото лице, което има фактическа власт върху отпадъците. 
legislative intent by the national formants, leads to qualify the EU "possession" as "material control on the good regardless of "animus domini". As a consequence, the consolidated EU concept "possesso, possessions, Besitz" in the Directive on Waste means "material control on the good in general".

Further research should be added, ${ }^{87}$ but in the opinion of the author of this article observation of national formants might contribute to the meaning of EU norms. Indeed, on close inspection, the nature of EU concepts as linguistic metaconcepts is likewise implicit in the case law of the CJEU. In the Cilfit case, by ruling that the legislative intent is to be found in all linguistic versions as a whole, the CJEU has left national courts and legislators free to uncover the legislative intent of the EU rule in question and so the concepts' legal meaning. Together with national case law, observing other formants might be useful too. The decree enforcing the Directive on Waste in Belgium leads to the same results. The fact that the Bulgarian version of the Directive has from the very beginning adopted the phrase "material control in general" regardless of the other language versions, is another aspect worthy of attention.

\section{Concluding Observations: Towards a European Restatement on EU Legal Language?}

After having described the evolution of the relationship between law and language in comparative law, this article has offered a necessarily brief overview on European multilingual law literature. Together with the attempt of giving the reader a general ideal of the state of the art, the aim of this survey of the main monographs on EU law and language was to observe the features of the debate on EU law and language and its impact as a whole. Although this field of research presumes scientific observations of a legal language formulated at the supranational level, this recent language phenomenon is framed into an institutional structure in which jurisdiction on EU law is attributed to national courts. Interestingly, the debate has generated attention on the impact of multilingualism in national courts too (particularly Dérlen and Baji), but in general studies are not concerned about the aspect of national judges establishing the meaning of a national norm having

87 Of particular interest are the Austrian and the German legal systems. As noted already, with regard to the regulation of "Besitz," the term is the same as in Austria. However, as the BGB does not prescribe the animus domini the legislative formant is different, but case law and scholarly opinions are aligned to the Austrian solution. As the EU legal language of Germany is the same as that of Austria in the Directive on Waste (i.e., "Besitz"), research will be carried out in order to verify how that meta-concept is turned into a consolidated German and Austrian EU concept. 
European origin; particularly, no attention is paid to the contribution of national case law in the construction of the EU conceptual structure. As already noted, for years the tendency in multilingual law studies was to focus on the CJEU as the only, or principal, actor of the juridical and linguistic consolidation of EU concepts.

The thesis in this article is that national case law (and formants in general) should also be observed as being crucial elements of the EU's hermeneutical process. In addition to the academic interest, there might be a different, more pragmatic reason to consider the role of the formants - national case law in particular - of the EU legal systems as important elements in the consolidation of an EU system of concepts.

In sharp contrast with its initial role of supranational jurisdiction on EU law, the CJEU is more and more sensitive to language issues and the number of cases in which its judgements do - directly or indirectly - contribute to clarify and consolidate EU concepts is constantly increasing. Nevertheless, the point at issue remains the practical effect CJEU case law has on the national level in clarifying the meaning of EU concepts. In other words, on when and how national judges would have knowledge of these "unofficial" supranational EU concept consolidations? The power of the idea that the CJEU is also the authority deciding on the meaning of the European autonomous concepts, in the light of the EU law harmonization process, is very low in national courts and, with the exclusion of specialists, in academic circles. If these are the results of the EU concept consolidation action by the CJEU, the visibility and the practical impact of national case law and other formants is rather weak.

Differently, from a national perspective, EU national courts are undergoing a process of cultural adaptation when applying EU law in their own legal language, as if they were European courts, interpreting concepts as composing a supranational order. This positive strive towards an effective autonomous and European interpretation of EU norms is probably part of a greater trend on a global and international level towards a more universal and interpretative approach, less positivistic and more relying on the hermeneutical criteria of supranational courts, CJEU in particular, ${ }^{88}$ in which comparative law is also playing an important role. ${ }^{89}$

88 Hannes Rösler, “Interpretation of EU law”. In Interpreting EU law, J. Basedow Basedow, K. J. Hopt, Reinhard (eds.) (Max Planck Encyclopedia of European Law, Vol. 2, Oxford, 2012): 979-982. 89 Joanna Jemielniak, and Przemysław Mikłaszewicz, "Introduction: Capturing the Change: Universalising Tendencies in Legal Interpretation”, in Interpretation of Law in a Global World: From Particularism to an Universal Approach, eds. J. Jemielniak and P. Miklaszewicz (Berlin, Heidelberg: Springer Verlag, 2010b), $15 \mathrm{ff}$. 
This orientation leads to believe that European normative concepts do exist when created, concurrently, by a legislative supranational declaration and a national formant. Especially, the contribution of national case law formants seems to be particularly considerable. However, the author is aware of the danger of excessively absolute conclusions in the absence of extensive research; as already clarified, not only does this study call for further research, but the EU hermeneutical process itself, and its results in terms of the creation of EU concepts, still require a long and extensive familiarization.

With a mere "food for thought" aim, the opportunity to channel European concepts in a compilation as an intellectual tool is suggested as a second, possible investment for future studies. One possible model of reference could be the Restatement, which, as is known, in the United States of America, restates state case law, then categorized into principles divided per topic.

The use of a restatement as an ostensible model towards the unification and harmonization of European private law was already discussed by Twining ${ }^{90}$; partly relying on a previous study by Beale. ${ }^{91}$ Twining listed similarities and differences among the restatement developed by the American Law Institute and various projects on the creation of common principles in Europe, the PECL for instance, or in general, initiatives on European private law (e.g., The Common Core of European Private Law, The Acquis Group).

Differently from this proposal, and from the American Restatement that is intended to restate case law in the form of principles, the European Restatement on EU legal language could restate EU concepts in specific areas of EU law. On an experimental basis, this would require some national formants of a number of Member States to contribute to clarify the EU meaning of a meta-concept and consequently turn it into a consolidated and possibly unique EU concept. However, as in the case of the American Restatement, it is desirable for the European instrument to also be an academic comparative law enterprise, leading EU concepts to gain a consolidated and universally known meaning. The initiative should work with academic - intellectual spirit towards the development of EU law and scientific collaboration and debate, also in order to immediately clear the field of any idea or fear of judicial supremacy ${ }^{92}$

90 William Twining, "Surface law", in Paradoxes of European Legal Integration, eds. H. Petersen, K.L. Kjaer and M.R. Madsen (Ashgate, Aldershot, 2008), 170-184.

91 Hugh Beale, “The European Civil Code Movement and the European Union's Common Frame of Reference”, Legal Information Management (2006), 4-11.

92 Janet Ainsworth, "Lost in Translation? Linguistic Diversity and the Elusive Quest for Plain Meaning in the Law”, in The Ashgate Handbook of Legal Translation, eds. L. Cheng, K.K. Sin, and A. Wagner, (Farnham Surrey (UK): Ashgate Ainsworth 2014), 51. 
The need for an orientation of European concepts towards a common direction was already underlined in the area of European property law and in the form of a specialized committee. ${ }^{93}$ The European Restatement could be a way to scientifically establish an EU conceptual framework in specific areas of EU law, monitoring the interpretation of terms in order to maintain equivalence, ${ }^{94}$ uncovering and solving terminological polysemies ${ }^{95}$ favouring legal certainty ${ }^{96}$ and a meaningoriented development of EU legal language.

The requirement underlying EU law is precisely its unique feature, equally in all Member States, which implies a common, uniform interpretation by national judges. ${ }^{97}$ It is because of this characteristic that the legal language of the EU has an inescapably instrumental aspect: as the ideal, ultimate expression of the EU metaconcept, each EU legal term is meant to lead to a positive outcome of the harmonization process, when the intention of the legislator is filtered into the meaning of normative concepts. As noted by Antonio Gambaro, this intention must not be qualified in a psychological sense, ${ }^{98}$ but requires the attribution of meaning to a norm that corresponds to the purpose assigned to it.

In the example of the 2008/98 Directive on waste, the intention of the legislator was to assign the duty to handle waste bearing the consequent costs to the person/ entities under whose control the waste was placed. In this regard, the case study on the concept "possession" is an example of how the uncovering of the EU meaning by the national court of the concept "possession" - "material control of the good in general" - was guided by the intent of the legislator and so to prescind from the juridical qualification of the animus domini.

Furthermore, from an economic point of view, uniformity in terminology and correspondence of meanings in EU law could have a positive impact in terms of

93 Sjef Van Erp, “European Private Law: A European Standing Committee on Legal Terminology as a Next Step?” (Editorial), EJCL, (2005).

94 Barbara Pozzo, "Comparative Law and the New Frontiers of Legal Translation", in Language and Culture in EU Law: Multidisciplinary Perspectives, ed. S. Šarčević (Abingdon Oxon (UK), New York (USA): Routledge, 2016), 84-85.

95 Elena Ioriatti, "Linguistic Precedent and Nomadic Meanings in EC Private Law". Revista General de Derecho Público Comparado (2009).

96 Stefaan Van Der Jeught, Current Practices with Regard to the Interpretation of Multilingual EU Law: How to Deal with Diverging Language Versions “, Eur. J. Legal Stud. 5, (2018-2019), 24.

97 Michel Mahieu, "L'interprétation du droit communautaire", in L'interprétation de droit. Approche pluridisciplinaire, ed. Van de Kerchove (dir.) (Brussels: Presses de l'Université SaintLouis, 2019), 350.

98 Antonio Gambaro, "Interpretation of Multilingual Legislative Texts”, Electronic Journal of Comparative law, vol. 11.3 (2007): 16. 
cost saving effects, ${ }^{99}$ as normative harmonization is effective when both definitions and operational rules correspond in the whole European Internal Market space.

Among the function of a European Restatement, legal education purposes should not be underestimated either. The process of uniformly interpreting EU law requires skill and expertise. An adequate pedagogical approach should assume not only the aim of furnishing theoretical knowledge, but also that of providing students and professionals with other abilities, that are essential for constructing their professional future in a multilingual legal environment. Thus, an educational model, ${ }^{100}$ like the one described above, integrating exercises into traditional teaching, might respond to this educational need. Furthermore, novel teaching methods on EU law should also integrate specific features of this unique legal system into their educational aims, and so, above all, the multilingual nature of its law. The language of teaching poses important goals and challenges, ${ }^{101}$ and consequently needs to combine the level of the substantive content of norms together with that of the EU legal language.

In order to seriously spread their educational message, the language of teaching should be flexible enough to be carried out in all national languages. In this regard, the construction of the consolidated concept and meaning in the example of the concept "possession" is neutral from a linguistic point of view and was previously illustrated by the author of this article in different languages (Italian, ${ }^{102}$ French, ${ }^{103}$ English $^{104}$ ), without the teaching message losing its legal

99 Helmut Wagner, "Economic Analysis of Cross-Border Legal Uncertainty: The Example of the European Union", in The Need for a European Contract Law: Empirical and Legal Perspectives, ed. J. Smits (Europa Law Publishing: Groningen, 2005), 27.

100 An experimental Winter School (Winter school P.A.R.O.L.E: Principles And Rules Over Languages in Europe), based on this methodology, will be offered in Winter 2020/21 in Trento (Italy), under the scientific supervision of the author of this chapter. The event is supported by the Faculty of Law, the University Foundation, and the Government of the Province of Trento.

101 Elena Ioriatti, 'Bilingual legal education in Italy: translating languages into teaching methods', in: N. Etcheverry (ed.), Bilingual Legal Education: The Need and the Challenges, New York: Springer, (forthcoming).

102 International Congress on "Comparing Legal Languages and Creating Common/Uniform Terminologies," University of Bologna, 2016; Annual Meeting of the Bar Associations, Trento, 2018. The meta-concept was also introduced in 2017 in the Accademia Nazionale dei Lincei, on the occasion of a speech on legal translation.

103 Laboratoire de droit comparé, Trento, 2017.

104 Round table "Multilingualism and EU Law: Bottom up or Top down?" Utrecht, 2018; Fondazione del Notariato, Rome, 2019; Hungarian Chamber of Notaries, Budapest, 2019; Exchange programme for judicial authorities, Consiglio Superiore della Magistratura, Trento, 2019; IMOLA II Closing Conference, European Land Registry Association (ELRA), Brussels, 2019; Seminar "Succession and Family law in theory and practice”, Bulgarian Foundation of Notaries, Fondazione del Notariato, Sofia, 2020. 
technical meaning or educational contribution. As Biel has noted "in EU law the mutual interdependence between the EU supranational and the national levels creates a hybrid conceptual and linguistic space, within which a new legal variant of the official languages emerges through multilingual translation."105 Here, comparative law works as a catalyst of the consolidated EU legal meaning, expressed in all these variants. In a wider context, it might be time for jurists and comparatists to reflect on how to shape the methodological and educational instruments to define, explain, and teach the content of this fascinating space.

Above all, also from the EU institutional side, uniformity of interpretation and application of EU law could be favoured and no longer remain a matter floating amid uncertainty, ${ }^{106}$ but gently suggested in an institutionalized dialogue among scholars and actors of the European legal language. ${ }^{107}$

\section{References}

Adams, M. 2014. "Controlled Comparison and Language of Description." In The Method and the Culture of Comparative Law. Essay in Honour of Mark Van Hoecke, Vol. 87, edited by M. Adams, and D. Heirbaut. Oxford and Portland, Oregon: Hart Publishing.

Ainsworth, J. 2014. "Lost in Translation? Linguistic Diversity and the Elusive Quest for Plain Meaning in the Law." In The Ashgate Handbook of Legal Translation, edited by L. Cheng, K. K. Sin, and A. Wagner, 43-55. Farnham Surrey (UK): Ashgate.

Austin, J. L. 1962. How to Do Things with Words. Oxford: Oxford University Press.

Baaij, C. 2018. Legal Integration and Language Diversity. Rethinking Translation in EU Lawmaking. New York: Oxford Studies in Language and Law.

Ballin, E. M. H., and L. A. Senden. 2005. Co-authorship in the Development of European LawMaking. The Quality of European Legislation and its Implementation and Application in the National Legal Order. The Hague, The Netherlands: T.M.C. Asser Press.

Batu, B. 2012. "An Overview of the Field of Semiotics." Procedia - Social and Behavioral Sciences: 464-9.

Beale, H. 2006. "The European Civil Code Movement and the European Union's Common Frame of Reference.” Legal Information Management: 4-11.

105 Vilelmini Sosoni and Lucja Biel, "EU Legal Culture and translation”, JLL 7 (2018), 3.

106 As already mentioned, fifteen years ago "judges and lawyers dealing with issues in the field of European law should study what has been done in other member states for those same issues, unless it were absolutely impossible to do for matters related to costs and time": Konrad Schiemann, "The judge as comparatist". In Judicial Recourse to Foreign Law: a new source of inspiration?, ed. B. Markesinis and J. Fedtke (London, New York: Routledge, 2006), 358.

107 The Restatement could guide the evolution of EU legal language at the EU level too, language which is currently centered on "words" and on "conceptual meanings" rather than on a systematic conceptual juridical context (Elena Ioriatti, "Lingua e diritto", in Temi e istituti di diritto privato dell'Unione Europea, eds. G. Benacchio \& F. Casucci, Padua: Cedam, 2017) 225). 
Beaupré, M. 1986. Interpreting Bilingual Legislation, 2nd ed. Toronto: Carswell.

Bell, J., and D. Ibbetson. 2012/2014. European Legal Development. The case of Tort, Cambridge: Cambridge University Press. Comparative studies in the Development of the Law of Tort in Europe, vol. 9, xii + 213.

Bobic, A. 2019. "The Shared System of Rules in a Polycentric European Union.” In Polycentricity in the European Union, edited by J. Van Zeben, and A. Bobic, 141-62. Cambridge: Cambridge University Press.

Bussani, M., and U. Mattei. 1997/1998. "The Common Core Approach to the European Private Law." Columbia Journal of European Law: 339-56.

Bussani, M., and U. Mattei. 2012. The Cambridge Companion to Comparative Law. Cambridge: Cambridge University Press.

Castellani, L., and R. Sacco. 1999. Les Multiples Langues du Droit Européen Uniforme. Turin: Harmattan.

Cheng, L., W. Cheng, and S. King Kui. 2014. "Revisiting Legal Terms: A Semiotic Perspective.” Semiotica 202: 167-82.

Cheng, L., S. King Kui, and A. Wagner, eds. 2014. The Ashgate Handbook on Legal Translation. Abingdon Oxon (UK), New York (USA): Routledge.

Cornu, G. 2005. Linguistique Juridique. Paris: Montchrestien.

Creech, R. 2005. Law and Language in the European Union: The Paradox of a Babel "United in Diversity". Amsterdam: Europa Law Publishing.

Derlén, M. 2007. A Castle in the Air: The Complexity of the Multilingual Interpretation of European Community Law. Umeå (Sweden): Umeå Studies in Law.

Derlén, M. 2009. Multilingual Interpretation of European Community Law. The Hague, New York: Kluwer Law International.

De Groot, R. 1988. "Problems of Legal Translation from the Point of View of a Comparative Lawyer." In Translation, Our future/La Traduction, Notre Avenir, edited by P. Nekeman, 407-21. Proceedings of the XIth Congress of FIT, Maastricht.

De Groot, R. 1999. “Das Übersetzen Juristischer Terminologie.” In Recht und Übersetzen, edited by G. R. Schulze. Baden-Baden (D): Nomos.

De Saussure, F. 1916. Cours de Linguistique Générale. Paris: Payot \& Cie.

Engberg, J. 2012. "Word Meaning and the Problem of a Globalized Legal Order." In The Oxford Handbook of Language and Law, edited by P. M. Tiersma, and L. M. Solan, 175-86. Oxford (UK): Oxford University Press.

Engberg, J. 2016. “Autonomous EU Concepts - Fact or Fiction?” In Language and Culture in EU Law: Multidisciplinary Perspectives, edited by S. Šarčević, 169-82. Abingdon Oxon (UK), New York (USA): Routledge.

Erp van, S. 2005. European Private Law: A European Standing Committee on Legal Terminology as a Next Step? (Editorial), EJCL. https://www.ejcl.org/92/editor92.html.

Esser, J. 1972. Vorverständnis und Methodenwahl in der Rechtsfindung. Frankfurt (Germany): Athenäum Fischer Verlag.

Ferreri, S. 2016. "Loyal to Different Exclusive Masters: Language Consistency at the National and Supranational Level." Statute Law Review: 172-81.

Freeman, M., and F. Smith. 2013. Law and Language. Oxford: Oxford University Press.

Gadamer, H. G. 1960. Wahrheit und Methode: Grundzüge einer philosophischen Hermeneutik. Tubingen (Germany): Mohr.

Galdia, M. 2003. “Comparative Law and Legal Translation.” The European Legal Forum (E) 1: 1-4. 
Gambaro, A. 1998. “Jura et Leges nel Processo di Edificazione di un Diritto Privato Europeo.” Europa e Diritto Privato: 993-1018.

Gambaro, A. 2004. “A proposito del Plurilinguismo Legislativo." Rivista Trimestrale di Diritto $e$ Procedura Civile: $287-300$.

Gambaro, A. 2007. "Interpretation of Multilingual Legislative Texts." Electronic Journal of Comparative Law 11 (3): 1-20.

Gémar, J. C., (dir.). 1979. “La Traduction Juridique” (special issue). In Meta. Journal des traducteurs, Vol. 24, 1.

Gémar, J. C., and N. Kasirer. 2005. Jurilinguistics: between Law and Language. Jurilinguistique: Entre Langues et Droit. Bruxelles; Bruylant: Montréal: Thémis.

Graziadei, M. 2016. "Law, Language and Multilingualism in Europe: The Call for a New Legal Culture." In Language and Culture in EU Law: Multidisciplinary Perspectives, edited by S. Šarčević, 17-32. Abingdon Oxon (UK), New York (USA): Routledge.

Hartkamp, A. S. 2011. Towards a European Civil Code, 4th rev. and exp. ed. Alphen aan den Rijn: Kluwer Law International.

Ioriatti, E. 2009. “Linguistic Precedent and Nomadic Meanings in EC Private Law.” Revista General de Derecho Público Comparado.

Ioriatti, E. 2013. Interpretazione Comparante e Multilinguismo Europeo. Padua: Cedam.

Ioriatti, E. 2016. “Formulation of Rights and European Legal Discourse: Any Theory behind it?" International Journal of Legal Discourse: 375-400.

Ioriatti, E. 2017. “Lingua e Diritto.” In Temi e Istituti di Diritto Privato dell'Unione Europea, edited by G. Benacchio, and F. Casucci, 225-36. Padua: Cedam.

Ioriatti, E. forthcoming. "Bilingual Legal Education in Italy: Translating Languages into Teaching Methods." In Bilingual Legal Education: The Need and the Challenges, edited by N. Etcheverry National reports, 20th Congress of the International Academy of Comparative Law (Fukuoka, General Congress). New York: Springer.

Jayme, E. 2000. Langue et Droit, XV International Congress of Comparative Law (Bristol 1998), Collection des rapports. Bruxelles: Bruylant.

Jemielniak, J., and P. Miklaszewicz. 2010a. Interpretation of Law in a Global World: From Particularism to a Universal Approach. Berlin, Heidelberg: Springer-Verlag.

Jemielniak, J., and P. Miklaszewicz. 2010b. "Introduction: Capturing the Change: Universalising Tendencies in Legal Interpretation." In Interpretation of Law in a Global World: From Particularism to a Universal Approach, edited by J. Jemielniak, and P. Miklaszewicz, 1-27. Berlin, Heidelberg: Springer-Verlag.

Jori, M., and A. Pintore. 2014. Filosofia del diritto. Turin: Giappichelli.

Klimas, T., and J. Vaiciukaite. 2005. "Interpretation of European Union Multilingual Law." International Journal of Baltic Law 3: 1-13.

Künnecke, M. 2013. “Translation in the EU: Language and Law in the EU's Judicial Labyrinth.” MJ 2: 243-60.

Mahieu, M. 2019. "L'interprétation du droit communautaire". In: L'interprétation de droit. Approche Pluridisciplinaire, edited by Van de Kerchove (dir.), 349-83. Brussels: Presses de l'Université Saint-Louis.

Malmkjær, K., and K. Windle. 2011. The Oxford Handbook of Translation Studies. Oxford: Oxford University Press.

Markesinis, B., and J. Fedtke. 2006. Judicial Recourse to Foreign Law: A New Source of Inspiration? London, New York: Routledge.

Mattila, H. E. 2006. Comparative Legal Linguistics. Aldershot: Ashgate. 
McGuire, M. R. 2011. "National Report on Germany." In National Reports on the Transfer of Movables in Europe, Vol. 3, edited by W. Faber, and B. Lurger, 1-192. Munich: Sellier, European law publishers $\mathrm{GmbH}$.

Moréteau, O. 1999 “L’anglais pourrait-il devenir la langue juridique commune en Europe?” In Les multiples langues du droit européen uniforme, edited by R. Sacco, and L. Castellani. Turin: Harmattan.

Moréteau, O., A. Masferrer, and K. A. Modéer. in the print. Comparative Legal History. Elgar online https://www.elgaronline.com/view/edcoll/9781781955215/9781781955215.xml.

Ost, F. 2014. "Law as Translation." In The Method and the Culture of Comparative Law. Essay in Honour of Mark Van Hoecke, edited by M. Adams, and D. Heirbaut, 69-86. Oxford and Portland, Oregon: Hart Publishing.

Palmer, V. V. 2004. "From Lerotholi to Lando: Some Examples of Comparative Law Methodology." Global Jurist Frontiers: 1-29.

Paunio, E. 2013. Legal Certainty in Multilingual EU Law. Language, Discourse and Reasoning at the European Court of Justice. Farnham, Surrey (UK): Ashgate.

Peirce, C. S. 1895. "What Is a Sign?" CP 2: 285.

Pes, L. 2012. Teorie dello Sviluppo Giuridico. Dal Movimento di law and Development All'esperienza Neoliberale. Trento (Italy): Tangram edizioni scientifiche.

Petersen, H., A. L. Kjær, and M. R. Madsen. 2008 In Paradoxes of European Legal Integration. Aldershot (UK), Burlington (USA): Ashgate.

Pommer, S. E. 2012. "Interpreting Multilingual EU Law: What Is the Role of Legal Translation?" European Review of Private Law: 1241-54.

Pozzo, B. 2016. “Comparative Law and the New Frontiers of Legal Translation.” In Language and Culture in EU Law: Multidisciplinary Perspectives, edited by S. Šarčević, 73-90. Abingdon Oxon (UK), New York (USA): Routledge.

Pozzo, B., and V. Jacometti. 2006. Multilingualism and the Harmonisation of European Law. The Hague: Kluwer law International.

Reimann, M., and R. Zimmermann. 2019. The Oxford Handbook of Comparative Law. Oxford: Oxford University Press.

Robertson, C. D. 2009. “LSP and EU Legal Language.” In Reconceptualizing LSP, edited by C. Heine, and J. Engber, 1-7. Online proceedings of the XVII European LSP Symposium.

Robertson, C. D. 2014. "EU Legislative Texts and Translation." In The Ashgate Handbook on Legal Translation, edited by L. Cheng, K. K. Sin, and A. Wagner, 159-176. Abingdon Oxon (UK), New York (USA): Routledge.

Robertson, C. D. 2016a. Multilingual Law. A Framework for Analysis and Understanding. Abingdon Oxon (UK), New York (USA): Routledge.

Robertson, C. D. 2016b. “EU Multilingual Law: Interfaces of Law, Language and Culture.” In Language and Culture in EU Law: Multidisciplinary Perspectives, edited by S. Šarčević, 33-52. Abingdon Oxon (UK), New York (USA): Routledge.

Rösler, H. 2012. “Interpretation of EU Law.” In Interpreting EU Law, edited by J. Basedow Basedow, and K. J. Hopt Reinhard, 979-82. Max Planck Encyclopedia of European Law, Vol. 2, Oxford.

Sacco, R. 1947. Il concetto di interpretazione del diritto. Turin: Libreria Scientifica Giappichelli (reprinted in 2003, preface by A. Gambaro). Turin: Giappichelli.

Sacco, R. 1965. “Définitions Savantes et Droit Appliqué dans les Systèmes Romanistes.” Revue Internationale de Droit Comparé: 827-37.

Sacco, R. 1991. "Legal Formants: A Dynamic Approach to Comparative Law." The American Journal of Comparative Law XXXIX: 1-34 and 343-402. 
Sacco, R. 2000. "Langue et Droit". In Langue et Droit, XV International Congress of Comparative Law (Bristol 1998), Collection des Rapports, edited by E. Jayme, 229-60. Brussels: Bruylant.

Sacco, R. 2003. L'interprétation des Textes Juridiques Rédigés Dans plus D'une Langue. Turin: Harmattan.

Sacco, R. 2008. “Dall'interpretazione Alla Traduzione”. In Interpretazione e Traduzione del Diritto, edited by E. Ioriatti, 3-12. Padua: Cedam.

Sacco, R. 2018. "Le passé, le Présent et le Future du Droit Comparé." In The Past, Present and Future of Comparative Law/ Le Passé, le Présent et le Future du Droit Comparé, Ceremony of 15 May 2017 in Honour of 5 Great Comparatistes/Cérémonie du 15 mai 2017 en l'honneur de 5 grands comparatistes, edited by K. Boele-Woelki, and D. P. Fernàndez Arroyo. Cham (Switzerland): Springer.

Sacco, R., and L. Castellani. 1999. Les Multiples Langues du Droit Européen Uniforme. Turin: Harmattan.

Sacco, R., and P. C. Rossi. 2019. Introduzione Al Diritto Comparato, 7th ed. Turin: Utet.

Šarčević, S. 2016. Language and Culture in EU Law: Multidisciplinary Perspectives. Abingdon Oxon (UK), New York (USA): Routledge.

Šarčević, S. 1997. New Approach to Legal Translation. The Hague: Kluwer Law International.

Schiemann, K. 2006. “The Judge as Comparatist.” In Judicial Recourse to Foreign Law: A New Source of Inspiration?, edited by B. Markesinis, and J. Fedtke, 358-373. London, New York: Routledge.

Schübel-Pfister, I. 2004. Sprache und Gemeinschaftsrecht - Die Auslegung der Mehrsprachig verbindlichen Rechtstexte durch der Europäischen Gerichtshof. Berlin: Duncker \& Humblot.

Searle, J. 1969. Speech Acts. An Essay in the Philosophy of Language. Cambridge: Cambridge University Press.

Sononi, V., and L. Biel. 2018. "EU Legal Culture and Translation." JLL 7: 1-7.

Tiersma, P. M., and L. M. Solan. 2012. The Oxford Handbook of Language and Law. Oxford: Oxford University Press.

Turi, J. G. 1990. “Le droit linguistique et les droits linguistiques." Les Cahiers de Droit: 641-50.

Twining, W. 2008. "Surface Law." In Paradoxes of European Legal Integration, edited by H. Petersen, K. L. Kjaer, and M. R. Madsen, 170-84. Aldershot (UK): Ashgate.

Von Bar, C., E. Clive, and H. Schulte-Nölk. 2009. Principles, Definitions and Model Rules of European Private Law: Draft Common Frame of Reference (DCFR). Munich: Sellier, European Law Publishers.

Van Der Jeught, S. 2015. EU Language and Law. Groningen (NL): Europa Law Publishing.

Van Der Jeught, S. 2018-2019. "Current Practices with Regard to the Interpretation of Multilingual EU Law: How to Deal with Diverging Language Versions.” European Journal of Legal Studies 5: 5-38.

Wagner, H. 2005. "Economic Analysis of Cross-Border Legal Uncertainty: The Example of the European Union." In The Need for a European Contract Law: Empirical and Legal Perspectives, edited by J. Smits, 27-51. Groningen: Europa Law Publishing.

Wagner, H., and J. C. Gémar. 2013. "Materializing Notions, Concepts and Language into Another Linguistic Framework." International Journal for the Semiotic of Law, Revue Internationale de Sémiotique Juridique 26: 731-45.

Wojciechowski, B. 2010. “Discourse Ethics as a Basis of Application of EU Law." In Interpretation of Law in a Global World: From Particularism to an Universal Approach, edited by J. Jemielniak, and P. Mikłaszewicz, 53-69. Berlin, Heidelberg: Springer-Verlag. 